\title{
KEPITING EKONOMIS PENTING, Portunus pelagicus DI INDONESIA
}

\author{
Oleh \\ Tyani Fitrian ${ }^{1)}$
}

\begin{abstract}
THE ECONOMICALLY IMPORTANT CRABS IN INDONESIA: Indonesia have many marine resources, one of it is crab. The worldwide have many spesies of crabs and the Indo-malaysia have approximatly 1000 spesies of crabs. During a few last years, the amount of crabs demand have increased. Portunidae is become one of the crabs which have important economic value in Indonesia. However, relying the production on natural capture gives on effect the number of crab populations has decreased.This paper discuss about charasteristios of crab especially Portunus pelagicus (Family : Portunidae) which have benefit economically value and should have managed wisely to become sustainable resources.
\end{abstract}

\section{PENDAHULUAN}

Kepiting merupakan subfilum dari krustasea, tubuhnya dilindungi oleh karapas dan memiliki sepuluh kaki dengan sepasang kaki depan yang berfungsi untuk mencapit. Jumlah krustasea di seluruh dunia diperkirakan mencapai 66.914 jenis (Ahyong et al., 2011), termasuk didalamnya 6.793 jenis kepiting (Brachyura) dari suku Portunidae (Ng et al., 2008; De Grave et al., 2009). Serène (1968) memperkirakan jumlah jenis kepiting di Asia Tenggara sekitar 2.500 jenis dan yang hidup di perairan Indo-Malaysia sebanyak lebih dari 1.000 jenis. Portunidae merupakan salah satu suku (family) dari kepiting (Brachyura) yang mempunyai nilai ekonomis penting di Indonesia. Jenis kepiting dari family Portunidae merupakan salah satu jenis kepiting yang memiliki daya jual yang tinggi di Indonesia. Jenis kepiting ini biasanya mempunyai ukuran karapas

1) Pusat Penelitian Oseanografi - LIPI dengan lebar sekitar $20 \mathrm{~cm}$, misalnya, Portunus pelagicu atau yang umum dikenal dengan sebutan rajungan. Data statistik dari perikanan tangkap Kementrian Kelautan Perikanan (KKP) pada tahun 2012, ekspor kepiting dan rajungan mencapai 28.211 ton dengan nilai US\$ 329.7 juta, meningkat menjadi 34.172 ton dengan nilai US\$ 359,3 juta, pada tahun 2013 dan data sementara tahun 2014 menyebutkan bahwa volume ekspor rajungan dan kepiting sebanyak 28.090 ton dengan nilai US\$ 414,3 juta. Ketergantungan produksi rajungan dan kepiting dari hasil penangkapan alam mengakibatkan menurunnya jumlah populasi rajungan maupun kepiting.

Sebagai negara yang mempunyai potensi perikanan cukup besar di bidang sumberdaya kepiting, maka masyarakat Indonesia harus mampu dan bisa memanfaatkan potensi perikanan yang ada sebagai media penghubung 
antarpulau sekaligus sebagai sumber daya kehidupan maritim. Jika dimanfaatkan secara arif, potensi kekayaan tersebut dapat mendukung pembangunan sosial ekonomi menuju masyarakat Indonesia yang maju, makmur dan berkeadilan. Tingkat pemanfaatan potensi perikanan khususnya jenis kepiting atau rajungan akan berpengaruh terhadap kelestarian stok di alam. Pendugaan potensi lestari yang kurang tepat dalam memilih teknik pengelolaan yang sesuai akan menyebabkan terjadinya overfishing. Apabila tingkat pemanfaatan masih dibawah potensi sumberdaya yang ada maka tidak akan banyak berpengaruh terhadap ketersedian stok, namun apabila tingkat pemanfaatan melebihi potensi yang ada maka akan membahayakan kelestarian stok ikan (rajungan/ kepiting). Tulisan ini merupakan telaah yang berdasarkan kajian pustaka yang bertujuan untuk mengkaji gambaran secara luas tentang komposisi jenis kepiting dari famili Portunidae yang mempunyai nilai ekonomis penting sehingga dapat dimanfaatkan secara arif dan berkelanjutan.

\section{RAJUNGAN EKONOMIS PENTING}

Jenis-jenis kepiting atau rajungan dari suku Portunidae yang mempunyai daya jual cukup tinggi dan dibudidayakan di Indonesia salah satunya yaitu Portunus pelagicus (rajungan biru). Di perairan tropis paling banyak ditangkap rajungan ( $P$. pelagicus). Ekspor rajungan Indonesia ditujukan ke beberapa negara dalam berbagai bentuk olahan. Rajungan terbanyak diekspor ke Singapura, Taiwan, Hongkong dan Malaysia. Rajungan beku diekspor ke Jepang, sedang kepiting beku diekspor ke Inggris (Business News dalam Moosa \& Juwana, 2007).

Rajungan menjadi salah satu diantara komoditas laut yang mempunyai nilai ekonomis tinggi di pasar dunia, namun demikian kebutuhan ekspor selama ini masih mengandalkan hasil penangkapan dari alam yang apabila mengalami eksploitasi tidak terkendali akan mengancam kelestarian sumber daya rajungan tersebut. Komoditas ini mempunyai kandungan gizi tinggi, sehingga menyebabkan komoditas ini sangat digemari oleh konsumen dalam ataupun luar negeri. Rajungan segar memiliki kandungan protein sebesar 68,09\%, mengandung 9 asam amino esensial dan 6 asam amino nonesensial (Jacoeb et al., 2012). Berdasarkan kandungan lemaknya, hasil perikanan (termasuk rajungan), dapat digolongkan menjadi 3 kelas, yaitu : golongan kandungan lemak rendah (kurang dari $2-3 \%$ ), golongan berlemak medium (2$5 \%$ ), dan golongan kandungan berlemak tinggi dengan kandungan lemak antara 6-20\%. Menurut Winarno (1993), rajungan termasuk dalam golongan berlemak medium/sedang dan dapat dikelompokkan bersama udang dan salmon.

Rajungan mempunyai rasa daging yang enak dan dapat diolah menjadi berbagai masakan, sehingga hewan ini sangat diminati oleh banyak masyarakat pecinta kuliner seafood. "Soft crab" atau rajungan lunak yang baru molting 
mempunyai harga berlipat-ganda dibandingkan produk lain (Juwana, 1997). Pengemasan dilakukan dengan cara mengambil rajungan yang masih lemah dan dibungkus dengan substrat yang lembab (misal rumput laut atau kertas), dan dikirim ke ruang pendingin seperti freezer.

\section{SISTEMATIKA Portunus pelagicus}

Rajungan merupakan sebutan umum untuk jenis kepiting Portunus pelagicus dari famili Portunidae yang hidup sepenuhnya di peraiaran laut. Nama Portunidae pertama kali dipergunakan oleh Rafinesque (1815). Sistematika dari Portunus pelagicus adalah sebagai berikut :

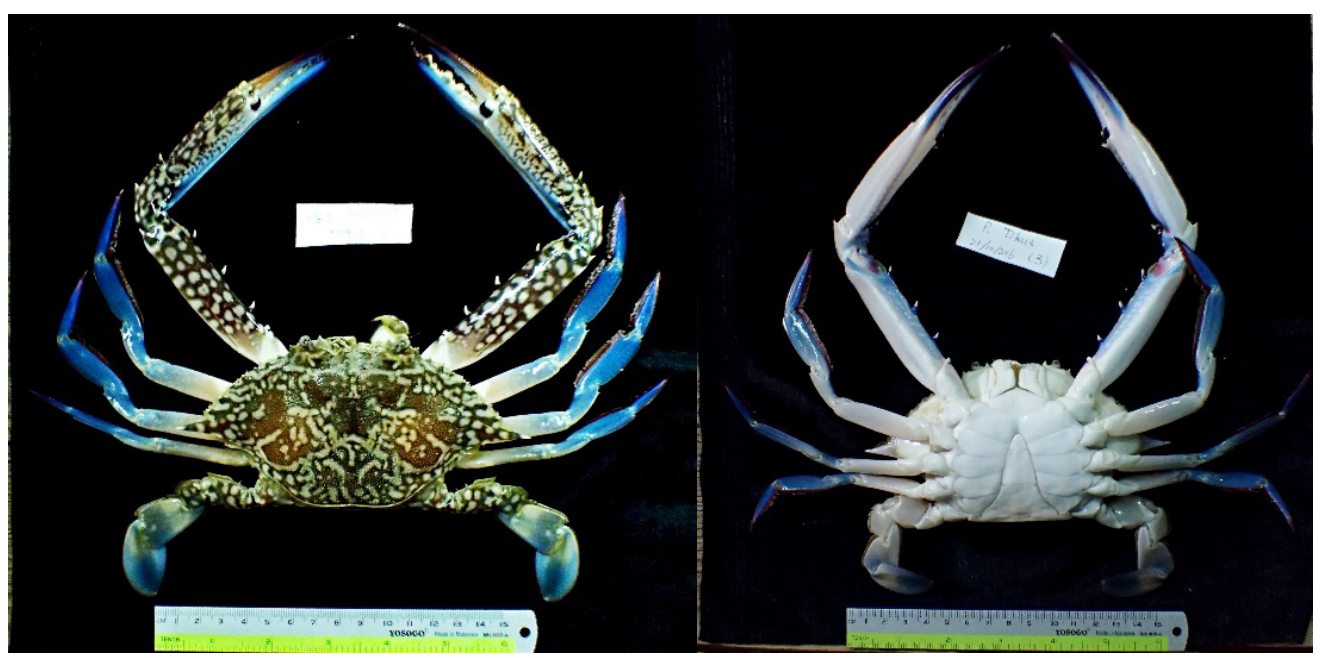

Gambar 1. Portunus pelagicus ( Rajungan). (Foto: koleksi pribadi) 


\section{ASPEK BIOLOGI Portunus pelagicus}

Portunus pelagicus atau yang lebih dikenal dengan nama rajungan biru menjadi salah satu komoditas ekspor penting dari Indonesia. rajungan ini memiliki daging yang sangat enak dan dapat diolah menjadi berbagai macam masakan, sehingga hewan ini sangat diminati para pencinta seafood (Sudhakar et al., 2009). Rajungan merupakan sebutan umum yang digunakan di Indonesia untuk jenis kepiting dari infra ordo Brachyura yang hidup sepenuhnya di laut. Menurut Secor et al.(2010), swimming crab di seluruh dunia didominasi oleh tiga spesies yaitu blue crab (Portunus trituberculatus) sebanyak $50 \%$, blue swimming crab (Portunus pelagicus) sebanyak $25 \%$ dan blue crab (Calinectes sapidus) 25\%.

Rajungan sangat mudah dikenali dari bentuk tubuhnya yang memiliki karapas lebar. Karapas rajungan berbentuk semitriangular dengan ornamen berbentuk titik-titik putih. Karapas rajungan dibagi menjadi beberapa bagian, yaitu ornamen pada bagian-bagian tersebut dapat menjadi ciri khas kematangan kelaminnya. Pada bagian dorsal tubuh rajungan terdapat toraks (thoranic strena) dan lipatan abdomen yang berwarna putih. Bentuk lipatan abdomen menjadi salah satu ciriciri untuk membedakan antara jantan dan betina. Rajungan memiliki tanda seksual dimorpisme atau perbedaan bentuk antara jantan dan betina. Biasanya jantan memiliki ukuran yang lebih besar dibandingkan dengan betina (Xiao \& Kumar, 2004). Menurut Lestang et al.
(2003), rajungan betina memiliki bentuk penutup abdomen yang lebar dengan bentuk menyerupai kubah, sedangkan rajungan jantan memiliki bentuk sempit, memanjang dan meruncing pada ujungnya.

Barnes (1987) menyatakan bahwa rajungan memiliki kemampuan berenang paling baik jika dibandingkan dengan krustasea lainnya. Di bagian anterolateral terdapat duri-duri yang berjumlah 9, dengan duri terakhir merupakan duri terbesar yang terletak di sisi karapas. Rajungan memiliki 5 pasang kaki jalan (periopod) dan satu diantaranya menjadi cheliped atau capit yang berfungsi menangkap mangsa.

\section{DAGING Portunus pelagicus}

Rajungan segar memiliki ciriciri, yaitu bersih, berbau harum (khas seafood), dagingnya putih mengandung lemak berwarna kuning dan bebas dari pengawet kimia, sedangkan kepiting yang sudah tidak segar dapat dilihat dari kulitnya yang terbuka dan meregang, daging telah mengering dan tidak terdapat lagi cairan dalam kulit, warna daging mulai berubah agak asam dan berbau busuk (Moeljanto, 1992). Menurut Yusuf (2007), standar daging rajungan yang dijadikan bahan baku untuk produk pasteurisasi (pasteurisasi crab meat) adalah yang memiliki daging dengan kualitas excellent atau first grade dengan kriteria sebagai berikut :

1. Kenampakan : bersih, cemerlang dan seragam.

2. Bau : spesifik rajungan segar, tajam. 
3. Tekstur: padat kompak.

4. Rasa : sangat manis

Sedangkan kriteria daging rajunagan yang tidak diterima atau second grade yaitu :

1. Kenampakan : kurang cemerlang dan terdapat serpihan shell

2. Bau : mengarah ke netral

3. Tekstur : kurang kompak

4. Rasa : manis

Bentuk produk rajungan yang menjadi komuditi ekspor yang dipasarkan ke negara-negara luar yaitu dalam bentuk produk kaleng daging rajungan. Pengelompokan daging rajungan dilakukan pada saat rajungan dikupas, dimana grade dagingnya dibagi menjadi 7 bagian di antarnya : Jumbo Colosal, Jumbo Biasa, Lump, Backfin, Special, Clawmeat dan Cocktail Claw. Menurut SNI No 6929-2016, 7 grade bagian tersebut didefinisikan sebagai berikut :

1. Jumbo: bagian daging rajungan terbesar yang terletak pada bagian badan yang berhubungan langsung dengan kaki renangnya.

Jumbo Colosal : Berat $>9$ gram.

Jumbo Biasa: Berat 5-9 gram

2. Clawmeat: daging merah yang merupakan daging dari bagian kaki jalan, renang sampai capit.

3. Backfin: daging putih yang merupakan jumbo kecil dan pecahan dari daging jumbo.

4. Lump: daging putih terdiri dari tiga ruas yang menyatu berbentuk seperti bunga yang berada pada bagian dada.

5. Spesial: daging putih berupa serpihan-serpihan yang berada di sekitar badan.

6. Cocktai: clawmeat yang masih ada kulit dan capitnya.

Harga termahal adalah harga grade jumbo colosal yaitu mencapai US \$ $15.085(\operatorname{Rp~182.649,-)~per~Ib,~}$ dan grade paling murah adalah cocktail claw dengan rata-rata harga mencapai US \$ 5.5 (Rp 66.594,-) per Ib, sehinga rata-rata harga ekspor per $\mathrm{Ib}$ kaleng produk rajungan adalah US \$ 10.891 (Rp $131.868,23$ ) dan harga per $1 \mathrm{~kg}$ daging produk rajungan yang dijualkan kepada pihak importir sekitar US \$ 23.99 (Rp 290.470,-) (Agustina, 2014).

\section{DISTRIBUSI DAN HABITAT Portunus pelagicus}

Kelimpahan Portunus pelagicus baik jantan maupun betina sangat bervariasi dalam suatu perairan, yang disebabkan oleh beberapa faktor seperti: stabilitas kualitas air dan komposisi sedimen (pasir, lumpur berpasir atau pasir berlumpur). Berdasarkan hasil beberapa penelitian yang pernah dilakukan, rajungan memiliki penyebaran yang luas, karena dapat hidup pada perairan tropis maupun subtropis. Distribusi rajungan jenis Portunus pelagicus meliputi berbagai negara seperti: Uni Emirat Arab, Pakistan, Saudi Arabia, Yaman, Mesir, Zanzibar, Mozambique, Afrika Selatan, Madagaskar, Oman, India, Srilangka, Thailand, Malaysia, Jepang, Korea, Taiwan, China, Singapura, Philipina, Indonesia, Papua Nugini, Calendonia Baru, Australia, Selandia Baru, Tahiti, 
Tanzania, Turki (Marine Species Identification Portal, 2010).

Rajungan memiliki habitat yang beragam, dimulai dari daerah pantai dengan dasar pasir bercampur dengan rumput laut dan seagrass di pulau berkarang dan juga laut terbuka, rajungan juga dapat ditemukan di daerah mangrove, di tambak-tambak air payau yang berdekatan dengan air laut (Juwana, 1997). Menurut Nontji (2007), rajungan dewasa hidup di dasar perairan sedangkan stadium larva dan megalopa berenang terbawa arus dan hidup sebagai plankton. Rajungan juga terdapat pada habitat lamun dan rumput laut yang tersebar luas pada substrat lumpur dan pasir dari zona intertidal sampai pada kedalaman mencapai 50 m (Edgar, 1990). Rajungan kecil sering ditemukan pada perairan lebih dangkal sedangkan rajungan dewasa ditemukan pada perairan yang lebih dalam. Rajungan dewasa mampu menempuh jarak hampir $20 \mathrm{~km}$ per hari (Kangas, 2000).

Dasar perairan laut memiliki tekstur yang berbeda-beda pada setiap lokasi, umumnya perairan terdiri dari tiga jenis substrat antara lain : pasir, lumpur dan tanah (liat). Berdasarkan penelitian
Yokes et al. (2007) rajungan ditemukan pada perairan berbatu dan substrat pasir halus, namun penelitian yang dilakukan Foka et al. (2004), menemukan rajungan pada substrat pasir lumpuran.

\section{DAUR HIDUP Portunus pelagicus}

Menurut Kangas (2000) mengatakan bahwa $P$. pelagicus mempunyai siklus hidup yang terdiri dari lima tingkat larva yang dilalui selama 26-45 hari. Tahap juvenil meliputi crab I-VII. Crab I didefinisikan sebagai moulting pertama dari tahap larva megalopa sampai tahap crab I ( Romano \& Zeng 2007). Lama perkembangan dari crab I sampai crab VII sekitar 40 hari. Terdapat empat fase zoea dan 1 fase megalopa selama perkembangan larva rajungan. Perkembangan zoea I menjadi II membutuhkan waktu 2-3 hari. Perkembangan zoea II, zoea III sampai IV yang masing-masing fase membutuhkan waktu 2 hari. Setelah fase zoea, maka rajungan memasuki fase megalopa dan selanjutnya menjadi crab I sama IV yang masing-masing fasenya berselang sekitar 5-10 hari yang kemudian menjadi rajungan muda (Juwana \& Romimohtarto, 2000). 


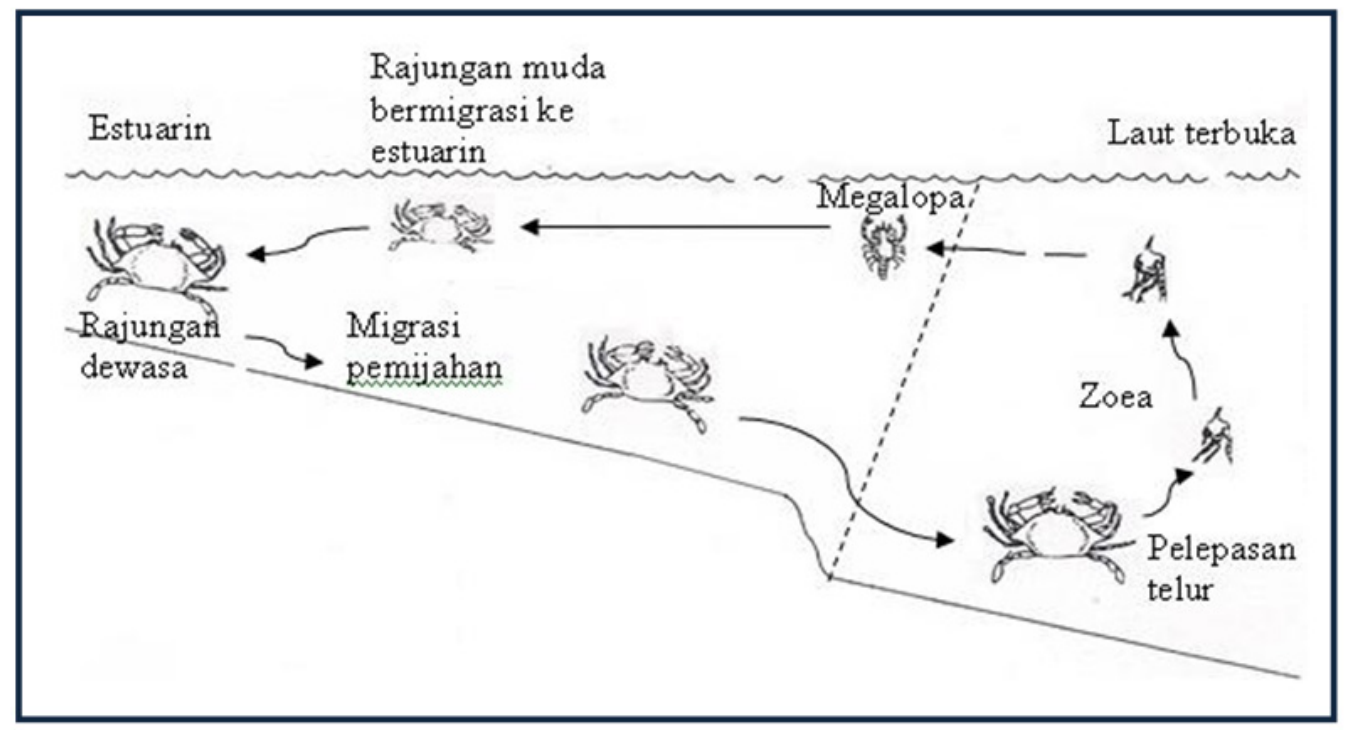

Gambar 2. Daur Hidup Portunus pelagicus ( Sumber : Nyabakken dan Bertness, 2004).

Umumnya, rajungan jantan dan betina mencapai kematangan gonad pada ukuran lebar karapas sekitar 70$90 \mathrm{~mm}$, dan ketika umurnya mendekati satu tahun. Musim pemijahan dilewati selama 3-4 bulan melewati musim panas. Durasi musim pertumbuhan bervariasi antar individu, disebabkan rajungan menempati (settling) pada awal musim panas akan memiliki waktu pertumbuhan yang lebih lama dibandingkan dengan yang menempati pada pertengahan atau akhir musim panas (Meagher, 1971). Rajungan jantan yang matang melepaskan cangkangnya (moulting) beberapa minggu sebelum periode moulting betina. Rajungan jantan membawa seekor betina yang dicapit dibawahnya selama 4-10 hari sebelum betina moulting (yang biasa disebut dengan "berpasangan"/"coupling"). Perkawinan terjadi setelah betina moulting, dan ketika cangkangnya masih lunak. Sperma disimpan secara internal dalam spermatheca, tetapi pembuahan terjadi secara eksternal. Telur-telur yang telah dibuahi diletakkan dalam bagian abdomennya dan memiliki bentuk seperti busa. Rajungan jantan dapat kawin dengan sejumlah rajungan betina pada saat musimnya. Pemijahan rajungan terjadi sepanjang tahun baik di perairan tropis maupun subtropis, meskipun betina lebih sering memijah pada musim kering di perairan tropis dan dimusim semi di perairan subtropis.

\section{MANAJEMEN PENGELOLAAN SUMBER DAYA (RAJUNGAN)}

Menurut Link (2010), pengelolaan sumber daya laut(living marine resources) yang lebih baik dapat dilakukan dengan pendekatan berbasis ekosistem, yaitu indikator-indikator ekosistem akan diterjemahkan menjadi kriteria keputusan, 
antara lain dengan mengidentifikasi indikator kunci dan mengevaluasi berapa banyak/persentase fungsi dari usaha penangkapan, serta mengintegrasi beberapa indikator yang mewakili semua proses dalam suatu ekosistem. Menurut UU No. 31 tahun 2004, pengelolaan perikanan didefinisikan sebagai seluruh upaya, proses yang terintegrasi dalam pengumpulan informasi, analisis, perencanaan, konsultasi, pembuatan keputusan, alokasi sumberdaya ikan dan implementasi, serta penegakan hukum dari peraturan perundang-undangan di bidang perikanan, yang dilakukan oleh pemerintah atau otoritas lain.

Pengelolaan perikanan sangat diperlukan beberapa tindak untuk menjamin kelestarian sumber daya tersebut. Menurut Charles (2001) tindakan-tindakan tersebut meliputi: pembatasan alat (gear restricted), pembatasan ukuran (size limit), penutupan musim (close season), dan penutupan lokasi penangkapan (close area). Tindakan tersebut dilakukan agar sumber daya perikanan dapat melakukan proses rekruitmen yang dapat meningkatkan stok "rajungan" pada suatu wilayah tertentu. Restocking juga merupakan salah satu upaya penambahan stok organisme target tangkapan untuk ditebarkan di laut, pada perairan yang dianggap telah mengalami penurunan stok akibat padat tangkap (fully exploited) atau tingkat pemanfaatannya berlebihan (overfishing). Restocking melibatkan kegiatan melepaskan biota seperti rajuangan hasil budidaya ke suatu perairan tertentu. Menurut Bell et al. (2006), restocking dapat berjalan secara efektif dalam mencapai tujuan pengelolaam apabila dilakukan dalam kondisi dan pengelolaan yang tepat.

\section{BUDIDAYA Portunus pelagicus (RAJUNGAN)}

Salah satu cara pengelolaan sumber daya rajungan agar dapat menjadi sumber daya yang berkelanjutan yaitu dengan cara dibudidayakan. Menurut Juwana (1997), terdapat tahapantahapan budidaya rajungan yang harus diperhatikan meliputi : (1) Kondisi lingkungan optimum dalam sistem budidaya; (2) Pengunaan pakan buatan; dan (3) Penebaran benih rajungan kembali ke alam (restocking).

\section{KEBIASAAN MAKAN}

Rajungan merupakan biota karnivora yaitu pemakan dasar, memakan berbagai macam invertebrata sesil dan yang bergerak lambat (Williams, 1982). Makanan utama bagi Portunus pelagicus yang hidup di daerah intertidal adalah hermit crab kecil dan gastropoda, sedangkan untuk Portunus pelagicus yang hidup di daerah subtidal adalah bivalve atau ophiuroidae. Hasil penelitian Chande \& Mgaya (2004) bahwa makanan utama rajungan antara lain adalah moluska, krustacea, tulang ikan dan jenis makanan yang didominasi oleh bivalvia ordo Mytiloida dari jenis Arcuatula arcuatula.

\section{PENUTUP}

Rajungan mempunyai permintaan pasar yang cukup tinggi dari tahun ke 
tahun. Pengelolaan yang baik dan tepat terhadap sumber daya tersebut sangat diperlukan untuk menjamin kelestarian. Kepiting ini merupakan sumber daya yang dapat diperbaharui (renewable resources), namun pemanfaatannya harus mematuhi prinsip-prinsip kelestarian sumber daya agar tingkat pemanfaatannya tidak melebihi tingkat penyediaan di alam.

Upaya budidaya adalah menjadi salah satu hal yang penting dalam mengelola sumberdaya. Oleh karena itu, perlu dilakukannya penyuluhanpenyuluhan terhadap nelayan untuk dapat mengelola sumber daya kepiting tersebut, hal ini dilakukan agar sumberdaya dapat melakukan proses rekruitmen yang dapat meningkatkan produksi kepiting pada suatu wilayah dengan waktu tertentu.

\section{DAFTAR PUSTAKA}

Afrianto, E., dan E, Liviawaty. 1992. Pemeliharaan

Kepiting. Penerbit Kanisius. Yogyakarta. $74 \mathrm{hlm}$.

Agustina, E.., A.K.Mudzakir., T. Yulianto. 2014. Analisis Distribusi Pemasaran Rajungan (Portunus pelagicus)DiDesaBetahwalang Kabupaten Demak. Journal of Fishries Resources Utilization Management and Technology.3(3): 190-199.

Ashong, S. T., J. K. Lowry, M. Alonso, R. N. Bamber, G. A. Boxshall, P. Castro , S. Gerken, G. S. Karaman, J. W. Goy, D. S. Jones,
K. Meland,D. C. Rogers, and J. Svavarsson. 2011. Subphylum Crustacea Brünnich, 1772. In: Zhang, Z.-Q. (Ed.). Animal biodiversity: An outline of higher-level classification and survey of taxonomic richness. Zootaxa. 3148:165-191.

Barnes, R.D. 1987. Invertebrate Zoology. 5th. Edition. Saunders. Sollege Publishing. Philadelphia. 836 p.

Bell, J. D., Leber, K. M., Blankenship, H. L., Loneragan, N. R., \& Masuda, R. (2008). A New Era for Restocking, Stock Enhancement and Sea Ranching of Coastal Fisheries Resources. Reviews in Fisheries Science, 16(1-3), 1-9.

Chande, AI, Mgaya YD. 2004. Food Habits of The Blue Swimming Crabs Portunus pelagicus Along the Coast of Dar es Salaam, Tanzania. Western Indian Ocean Journal of Marine Science 3(1), 37-42.

Charles, AT. 2001. Sustainable Fisheries System. Fish and Aquatic Resources series 5. Blackwell Science Ltd. Oxford.370 p

De lestang, S., Norman G. H. dan C.P. Ian. 2003. Reproductive Biology of Blue Swimming Crab (Portunus pelagicus, Decapoda : Portunidae)in Five Bodies of Water on the West Coast of Australia. Fishery Bulletin. 101: 745-757. 
Edgar, G.J.1990. Predator-prey interactions in seagrass beds. II. Distribution in diet of the blue manna crab, Portunus pelagicus (L) at Cliff Head, Western Australia. J.Exp. Mar. Biol.Ecol. 139:23-32.

Edwards, E. 1979. The Edible Crab and Its Fishriy in British Waters. Fishing News Books Ltd. Farnham, Surrey England. 142 p.

Foka, M.C, G. Kondylatos and P.S.Economidis. 2004. Occuranrence of the lessepsian spesies Portunus pelagicus (Crustacea) and Aapogon pharaonis (Pices) in the marine area of Rhodes Island. Medit. Mar, Sci, 5/1.83-89.

Jacoeb, A. M., Nurjanah, and L. A. Lingga. 2012. The Effect of Steaiming on Protein And Amino Acid Charactheristic of Crab (Portunus pelagicus) Meat. JPHPI. 15(2): 156-163.

Juwana, S. 1997. Tinjauan Tentang Perkembangan Penelitian Budidaya Rajungan (Portunus pelagicus). Oseana. Vol XXII.4: 1-12.

Juwana, S dan Romimohtarto, K. 2000. Rajungan : Perikanan, Cara Budidaya dan Menu Masakan. Djambatan Jakarta. 47 hlm.

Kangas, M.I. 2000. Synopsis of the biology and exploitation of the ble swimmer crab, Portunus pelagicus Linnaeus, in Western Australia Fisheries Research Report No. 121. Fisheries Western Australia. 22 p.

Link, JS. 2010. Translating ecosystem indicators into decision criteria. ICES Journal of Marine Science. 62 : 569-576.

Marine Species Identifikasi Portal(MSIP). $\mathrm{http}: / /$ species- identification. org/species.php?species group=crabs_of_japan\& $\mathrm{id}=1098 \&$ menuentry $=$ soorten. Diakses : 1 November 2018.

Moeljanto, R. 1982. Pendinginan dan Pembekuan Ikan. PT. Penebar swadaya. Jakarta.39 hlm

Moosa, M. K. danS. Juwana. 1996. Kepiting Suku Portunidae dari Perairan Indonesia (Decapoda, Brachyura). Pusat Penelitian dan Pengembangan Oseanologi. Lembaga Ilmu Pengetahuan Indonesia. Jakarta. 118 hlm.

Ng, P. K. L., D. Guinot, and P. J. F. Davie. 2008. System Brachyurorum: Part I. An ated checklist of extant brachyuran crabs of the world. Raff Bull Zool 17:1-286.

Nybakken, J.W., and M.D. Bertness.2004. Marine Biology. An Ecological Approach. Pearson. Benjamin Cummings. San Francisco. 592 p.

Nontji, A. 2007. Laut Nusantara. Ed revisi. Djambatan.Jakarta. 362 hal. 
Secor, D.H., A.H.Hines and A.R. Place. 2010. Japanese HatcheryBased Stock Enhancment : Lesson for the Cheaspeak Bay Blue Crab. Maryland Sea Grand. College Park Maryland. $43 \mathrm{p}$.

Serène, R. 1968. The Brachyura of the Indo Pacific Region. In: Prodromous of a Check List of the Non- Planktonic Marine Fauna of the Sout East Asia. Special Publication of the Singapore National Academic of Science. 1:33-120.

Siahainenia, L. 2008. Bioekologi kepiting bakau (Scyllaspp.) di ekosistem mangrove Kabupaten Subang, Jawa Barat [disertasi].Program Pascasarjana, Institut Pertanian Bogor. Bogor.289hlm.

Sudhakar M, K. Manivannan, and P. Soundrapandian. 2009. Nutritive value of hard and soft shell crabs of Portunus sanguinolentus(Herbst). Journal Animal and veterinary Advances 1(2): 44-48.

Williams, M.J. 1982. Natural food and and feeding in the commercial sand crab Portunus pelagicus Linnaeus 1766 (Crustacea: Decapoda : Portunidae) in Moreton Bay Queensland. Journal of Experimental Marine Biology and Ecology. Vol. 59. (2-3). 165-176.
Winarno, F.G. 1993. Pangan, Gizi, Teknologi dan Konsumen. PT Gramedia Pustaka Utama. Jakarta. $416 \mathrm{hlm}$.

Xiao, Y and M. Kumar. 2004. Sex Ratio and probability of sexual maturity of female at size of the blue wimmer crabs, Portunus pelagicus Linneaus off Southern Australia. Jour. Fishries Researcher. 68: 271282.

Yusuf, M. 2007. Kajian Pemasaran dan Pengembangan Value added product dengan [emanfaatan Rajungan menjadi Produk Olahan.[Tesis]. Universitas Diponogoro, Semarang.

Yokes, M.B., Karhan, S.U., Okus, E.,Yuksek, A., Aslan-Yilmaz, A., Yilmaz, N., Demirel, N., Demir, V., Galil, B.S. 2007. Alien Crustacean Decapodas from the aegnean Coast of Turkey. Aquatic Invasions 2(3);162-168. 